\title{
FAKTOR SOSIAL YANG BERPENGARUH TERHADAP PERGESERAN BAHASA LOWA
}

\author{
Ibrahim $^{a}$, Ruslan ${ }^{b}$, Muhammad Nur Ashar Asnurc $^{c}$, Yusniati N. Sabata ${ }^{d}$, Muhammad \\ Syahrul Kahar ${ }^{\mathrm{e}}$ \\ a,b,ePendidikan Bahasa Inggris, Fakultas Keguruan dan Ilmu Pendidikan, Universitas Muhammadiyah Sorong \\ 'Pendidikan Bahasa Jerman, Fakultas Bahasa dan Seni, Universitas Negeri Jakarta \\ ${ }^{d}$ Pendidikan Bahasa Inggris, Fakultas Keguruan dan Ilmu Pendidikan, Universitas Muhammadiyah Luwuk \\ *Corresponding author: ibrahim080988@gmail.com
}

\begin{tabular}{|c|c|}
\hline INFORMASI ARTIKEL & ABSTRAK \\
\hline $\begin{array}{l}\text { Sejarah Artikel } \\
\text { Diterima: } 18 / 8 / 2019 \\
\text { Direvisi: } 12 / 11 / 2019 \\
\text { Diterima: } 19 / 12 / 2019 \\
\text { Tersedia Daring: 30/12/2019 } \\
\text { Kata Kunci } \\
\text { Faktor Sosial } \\
\text { Pergeseran Bahasa } \\
\text { Bahasa Lowa }\end{array}$ & $\begin{array}{l}\text { Penelitian ini bertujuan untuk mengidentifikasi faktor sosial dan faktor } \\
\text { sosial yang dominan berpengaruh terhadap pergeseran bahasa Lowa } \\
\text { terhadap pergeseran bahasa Lowa. Pengumpulan data dilakukan dengan } \\
\text { tiga cara yaitu, dengan menggunakan kuesioner, wawancara, dan } \\
\text { observasi. Data penelitian terdiri atas data primer dan data sekunder. Hasil } \\
\text { penelitian ini diperoleh data bahwa ada tiga faktor sosial yang } \\
\text { memengaruhi pergeseran Bahasa Lowa meliputi: (1) Faktor jenis kelamin; } \\
\text { (2) Faktor umur); (3) Faktor Tingkat Pendidikan. Adapun faktor yang } \\
\text { paling dominan memengaruhi pergeseran Bahasa Lowa yakni faktor umur. } \\
\text { Bahasa Lowa sudah sangat jarang digunakan oleh anak-anak maupun anak } \\
\text { muda, penutur bahasa Lowa umumnya adalah masyarakat yang berusia tua. } \\
\text { Hal tersebut mengindikasikan bahwa kondisi bahasa Lowa sudah berada di } \\
\text { ambang kepunahan (nearly extinct). }\end{array}$ \\
\hline
\end{tabular}

\section{ABSTRACT}

$\begin{aligned} & \text { Keywords } \\ & \text { Social Factor } \\ & \text { Language Shift } \\ & \text { Lowa Language }\end{aligned}$
Lowa language. The data collection was carried out in three ways, namely
questionnaires, interviews, and observations. The research data consisted
of primary and secondary data. The results of this study show that there are
three social factors that influence the Lowa language shift; they are: (1)
gender factor; (2) age factor); (3) educational level Factors. The most
dominant factor influencing the Lowa language shift is age. The Lowa
language is rarely used by children and young people; the speakers of
Lowa are generally older people. This indicates that the condition of
Lowa's language is on the verge of extinction (nearly extinct).
Copyright@2019, Ibrahim, Ruslan, Muhammad Nur Ashar Asnur, Yusniati N.
Sabata, Muhammad Syahrul Kahar
This is an open access article under the CC-BY-3.0 license
(1)

\section{PENDAHULUAN}

Bahasa memiliki peranan yang sangat penting dan tidak dapat dipisahkan dari kehidupan manusia, hal ini dikarenakan bahasa merupakan salah satu penentu akan keberlangsungan hidup suatu masyarakat. Melalui bahasa manusia dapat menyampaikan maksud dan pikirannya, melalui bahasa pula manusia dapat berkomunikasi satu sama lain. Bahasa merupakan kemampuan komunikasi yang melibatkan orang lain untuk menyampaikan pesan (Wael, Asnur, \& Ibrahim, 2018). Selan itu, dapat dimaknai pula bahwa bahasa adalah 
alat komunikasi antara anggota masyarakat berupa simbol bunyi yang dihasilkan oleh organ tubuh manusia berupa alat ucap (Widianto \& Zulaeha, 2016).

Bahasa dapat menjadi salah satu faktor penentu perubahan suatu masyarakat. Walaupun demikian, hal itu terkadang kurang begitu dipahami bahkan tidak dipahami oleh penutur suatu bahasa, sehingga tanpa disadari sebuah peradaban termasuk bahasa yang ada di dalamnya mengalami pergeseran. Penggunaan suatu bahasa tidak dapat dipisahkan dari pengaruh sosial dan latar belakang budaya dari pengguna bahasa $(\mathrm{H}$. B. Mardikantoro \& Maretta, 2016).

Pergeseran bahasa pada umumnya mengacu pada proses penggantian penggunaan suatu bahasa dengan bahasa yang lainnya pada seorang penutur maupun pada suatu masyarakat tutur. Salah satu aspek penting dalam ranah penggunaan bahasa di masyarakat adalah pemilihan bahasa (language choice), yaitu dipilihnya bahasa tertentu dalam ranah tertentu (Lukman, 2014). Pergeseran suatu bahasa umumnya terjadi karena adanya persaingan bahasa pertama dengan bahasa kedua yang digunakan di dalam suatu masyarakat tutur. Hadirnya bahasa kedua dalam suatu masyarakat tutur menimbulkan persaingan atau kontak bahasa antara bahasa pertama (B1) dan bahasa kedua (B2) atau kedwibahasaan. Lukman (2014) mengemukakan bahwa situasi kedwibahasaan membawa pengaruh pada pemakaian dan pemilihan bahasa dalam berbagai ranah kehidupan, rumah, pasar, tempat kerja, dengan tetangga, tempat ibadah, sekolah, puskemas, kantor desa, kantor camat, kantor bupati, dan kantor polisi. Pilihan bahasa dapat pula dipengaruhi oleh faktor internal yaitu bahasa penutur dan faktor eksternal meliputi situasi, topik percakapan, dan maksud/tujuan tuturan (Widianto \& Zulaeha, 2016). Selain itu, pilihan bahasa yang digunakan dapat berupa variasi bahasa tunggal, alih kode, dan campur kode (Tamrin, 2018). Pemilihan kode tutur seseorang berpengaruh terhadap keefektifan dalam berkomunikasi sehingga penggunaan bahasa yang sesuai sebaiknya perlu agar pesan diterima dengan baik oleh pendengar (Eliya \& Zulaeha, 2017). Sayangnya hal tersebut dapat menentukan apakah bahasa pertama mereka akan bertahan atau sebaliknya akan bergeser.

Kajian mengenai pergeseran bahasa telah banyak dilakukan dan telah memberikan gambaran bahwa fenomena ini perlu diperhatikan, dikaji lebih jauh, serta diberikan solusi strategis menghadapi ancaman yang ada (G. Lukman, 2015; Raihany, 2015; Suparta, 2015). Faktanya adalah zaman semakin berkembang dan penutur B1 tentu akan memperoleh tantangan yang sangat besar pula (Darwis, 2011). Padahal diketahui bahwa Indonesia telah menetapkan dalam undang-undang bahwa B1 khususnya bahasa daerah perlu dilindungi dan tentu dilesatarikan karena itu adalah bagian dari budaya Indonesia.

Saat ini Indonesia mengalami tantangan terhadap pergeseran bahasa daerah yang berujung pada kepunahannya di seluruh pelosok negeri. Ibrahim (2011) mengidentifikasi bahasa daerah di Indonesia yang saat ini teracam punah dan hampir punah sebagian besar berada di wilayah timur Indonesia. Di wilayah Papua misalnya, telah diperoleh informasi bahwa delapan bahasa daerah telah punah. Begitupula tiga bahasa daerah di daerah Maluku juga telah punah. Mukhamdanah (2010) menambahkan hasil identifikasinya bahwa jumlah bahasa yang terancam punah meliputi: 1 bahasa daerah di kalimantan, 2 bahasa daerah di Sumatera, 36 bahasa di Sulawesi, 22 di Maluku, dan 8 bahasa di daerah Timor, Flores, Bima dan Sumba. Sedangkan jumlah bahasa yang telah punah masing-masing terdiri atas satu bahasa daerah baik di Kalimantan, Sumatera, Sulawesi, dan 11 bahasa daerah di Maluku.

Berdasarkan beberapa hasil penelitian tentang pergeseran bahasa yang telah dilakukan di Indonesia serta di negara-negara lain di dunia menunjukkan hasil bahwa pergeseran dan kepunahan bahasa daerah disebabkan oleh beberapa faktor, namun faktor-faktor yang menjadi penyebab pergeseran suatu bahasa tidak pernah sama dengan faktor-faktor penyebab pergeseran bahasa lainnya. Faktor-faktor sosial yang memengaruhi bahasa yang dipilih 
sebagai alat komunikasi efektif dalam masyarakat meliputi status sosial, jenis kelamin, umur, tingkat pendidikan, jabatan atau pekerjaan, dan keanggotaan seseorang dalam kelompok tertentu (Wodak, Krzyżanowski, \& Forchtner, 2012). Selain itu, Lukman (2014) menegaskan faktor lingkungan kerja juga sangat berperan menyebabkan terjadinya pergeseran bahasa. Berbeda halnya dengan G. Lukman (2015) yang mengungkapkan bahwa pengaruh sikap terhadap penggunaan B1 menyebabkan pergeseran bahasa oleh masyarakat desa dan kota. Faktor yang sangat mempengaruhi pergeseran bahasa adalah faktor pendidikan yang meningkatkan bahasa lain selain bahasa pertama (Nenoliu \& Mardikantoro, 2019). Adapun dampak yang dihasilkan oleh pergeseran bahasa adalah transformasi masyarakat penutur bahasa dari aspek kesederhanaan, tingkat pendidikan, teknologi, perkawinan, dan ekonomi (H. B. Mardikantoro \& Maretta, 2016).

Salah satu bahasa daerah yang juga sekarang mulai tergeser bahkan terancam punah adalah bahasa Lowa. Bahasa Lowa terdapat di dusun Lowa, desa Lowa, kecamatan Bontosikuyu, kabupaten Kepulauan Selayar. Pada kenyataannya di desa Lowa terdapat tiga dusun yakni dusun Podang, dusun Tongke-Tongke dan dusun Lowa, meskipun di desa Lowa terdapat tiga dusun, namun dusun yang warganya memakai bahasa Lowa hanya dusun Lowa, sementara kedua dusun lainnya masyarakatnya memakai bahasa Selayar. Hal tersebut seringkali menimbulkan pertanyaan tentang status bahasa Lowa sebagai bahasa atau dialek. Donohue (2004) dalam penelitiannya tentang status bahasa Lowa menyimpulkan bahwa bahasa Lowa merupakan bahasa dan bukan dialek dari bahasa Selayar. Dari hasil penelitiannya juga ditemukan bahwa bahasa Lowa merupakan salah satu bahasa dari subkelompok Kalao dalam rumpun bahasa Wotu-Wolio dan bukan merupakan dialek dari bahasa Selayar. Berdasarkan sejarahnya penduduk Lowa berasal dari Buton (P.Buton), dan mulai masuk ke Selayar pada tahun 1542, kelompok ini kemudian mendiami bagian ujung selatan Selayar yakni Laiyolo, Lowa, dan pulau Kalao. Adapun penyebaran (wilayah) pemakaian bahasa ini meliputi Lowa, Laiyolo, Kalao, Wotu, dan Wolio. Terdapat perbedaan yang sangat mendasar antara bahasa Lowa dengan bahasa Selayar. Berikut perbedaan antara bahasa Lowa dengan bahasa Selayar.

$\begin{array}{ll}\text { - } & \text { Beku }(B L) \\ \text { - } & \text { A'ra }(B S) \\ \text { - } & \text { Mau }(B I)\end{array}$
- Ne'e mukenassu!(BL)

- Ako kuku!

- Jangan marah!(BI)

Berdasarkan informasi yang diperoleh penulis melalui wawancara dengan kepala desa setempat, Muh. Arsyad (47 tahun), dari 506 orang penduduk Dusun Lowa, penutur asli bahasa Lowa tersisa 300-an orang dengan rata-rata usia 50-an tahun ke atas. Informasi lain yang diperoleh penulis dari hasil wawancara dengan informan, Muh. Yamin (50 tahun), mengatakan bahwa yang masih aktif menggunakan bahasa Lowa tersebut hanya orang tua yang berusia 70-80 tahun ke atas, selebihnya sudah menggunakan bahasa Selayar. Selanjutnya, dari hasil pengamatan yang dilakukan oleh penulis, umumnya masyarakat Lowa sudah menggunakan bahasa Selayar sebagai alat komunikasi mereka sehari-hari pada setiap ranah kehidupan mereka, terutama pada ranah rumah tangga.

Pada kenyataan di lapangan, pergeseran bahasa Lowa tidak hanya terjadi pada kalangan anak-anak maupun anak muda, tetapi juga terjadi pada para orang tua. Pergeseran yang dimaksud tersebut bukan hanya dikarenakan ketidaktahuan mereka mengenai bahasa Lowa, namun lebih pada keengganan mereka menggunakan bahasa tersebut. Dari hasil pengamatan yang dilakukan oleh penulis, ketika para orang tua tersebut berkomunikasi dengan anak-anak mereka, bahasa yang mereka gunakan adalah bahasa Selayar. Sementara, (Anderson, 2010) menyatakan bahwa untuk mengetahui suatu bahasa bergeser atau tidak, 
dapat dilihat pada komunikasi antara keluarga di dalam ranah rumah tangga yaitu bahasa orang tua kepada anaknya, anak terhadap orang tua, serta suami terhadap istri atau sebaliknya.

Berdasarkan hasil wawancara yang dilakukan terhadap beberapa informan, mereka mengatakan bahwa para orang tua lebih suka mengajarkan bahasa Selayar dan bahasa Indonesia daripada bahasa Lowa karena bahasa Selayar merupakan bahasa yang paling banyak digunakan di Selayar sehingga akan memudahkan anak-anak mereka untuk bergaul dengan masyarakat Selayar lainnya atau dengan teman-teman sekolah mereka. Sementara itu, mereka lebih suka mengajarkan bahasa Indonesia kepada anak mereka dengan alasan bahwa bahasa Indonesia merupakan bahasa nasional dan digunakan di seluruh Indonesia, sehingga mereka harus mengajarkan bahasa tersebut dari kecil kepada anak-anak mereka agar anakanak mereka tidak menemui kesulitan ketika melanjutkan pendidikan atau mencari kerja.

Berdasarkan fakta-fakta yang telah disebutkan sebelumnya serta beberapa penelitian terdahulu khususnya kajian tentang faktor yang mempengaruhi pergeseran beberapa bahasa daerah di nusantara (Diani, 2011; Lukman, 2014; G. Lukman, 2015; H. Mardikantoro, 2012; Raihany, 2015; Suparta, 2015) maka penelitian ini bertujuan untuk mengidentifikasi faktor sosial yang berpengaruh terhadap pergeseran Bahasa Lowa dan faktor yang dominan berpengaruh terhadap pergeseran Bahasa Lowa.

\section{METODE}

Penelitian ini merupakan penelitian gabungan antara kualitatif dan kuantitatif dengan menggunakan pendekatan sosiolinguistik. Populasi dalam penelitian ini adalah keseluruhan penutur asli bahasa Lowa yang ada di Dusun Lowa. Sampel dipilih secara acak sederhana (Simple Random Sampling). Sumber data penelitian ini terdiri atas dua yaitu data primer dan data sekunder. Data primer dalam penelitian ini adalah jawaban-jawaban pertanyaan yang diperoleh dari 72 kuesioner yang dikembalikan oleh responden, sedangkan data sekunder diperoleh dari hasil wawancara dengan beberapa informan, hasil pengamatan di lapangan serta data pendukung lainnya yang diperoleh dari kantor desa setempat. Lokasi penelitian ini adalah di Dusun Lowa, Kabupaten Kepulauan Selayar. Teknik yang dilakukan untuk mengumpulkan data dalam penelitian ini adalah dengan menggunakan kuesioner, wawancara dan observasi. Metode lainnya yang digunakan dalam penelitian ini adalah dengan studi kepustakaan, hal ini dilakukan untuk mencari dan mengumpulkan data dan informasi yang berhubungan dengan penelitian serta mendukung penelitian. Teknik analisis data yang digunakan untuk mengukur tingkat pergeseran bahasa dan pemilihan bahasa responden adalah teknik analisis statistik deskriptif tabulasi sederhana. Untuk menentukan faktor-faktor yang memengaruhi pergeseran bahasa Lowa, data kuantitatif diolah dengan menggunakan program SPSS. Data-data yang diperoleh tersebut selanjutnya dianalisis secara kualitatif dengan mendeskripsikan semua data yang ada.

\section{HASIL DAN PEMBAHASAN}

Berdasarkan tujuan penelitian, diperoleh data bahwa faktor sosial yang berpengaruh terhadap pergeseran Bahasa Lowa terdiri atas faktor jenis kelamin, faktor umur dan faktor tingkat pendidikan. Hal ini dilihat pada penggunaan bahasa pada masing-masing responden.

\section{Penggunaan Bahasa Berdasarkan Jenis Kelamin}

Perbedaan jenis kelamin seringkali menyebabkan perbedaan dalam pemilihan atau penggunaan bahasa, oleh karena itu penulis menjadikan perbedaan jenis kelamin tersebut sebagai salah satu variabel dalam penelitian ini. Berdasarkan hasil penelitian didapatkan penggunaan bahasa pada responden laki-laki sebagai berikut, bahasa Lowa 7,1\%, bahasa Selayar 59,5\%, bahasa Indonesia 2,4\%, bahasa campuran 30,9\%. Penggunaan bahasa pada 
responden perempuan sebagai berikut, bahasa Lowa 40\%, bahasa Selayar 46,7\%, bahasa Indonesia $0 \%$, dan bahasa campuran 13,3\%. Untuk lebih jelasnya dapat dilihat pada Grafik 1.

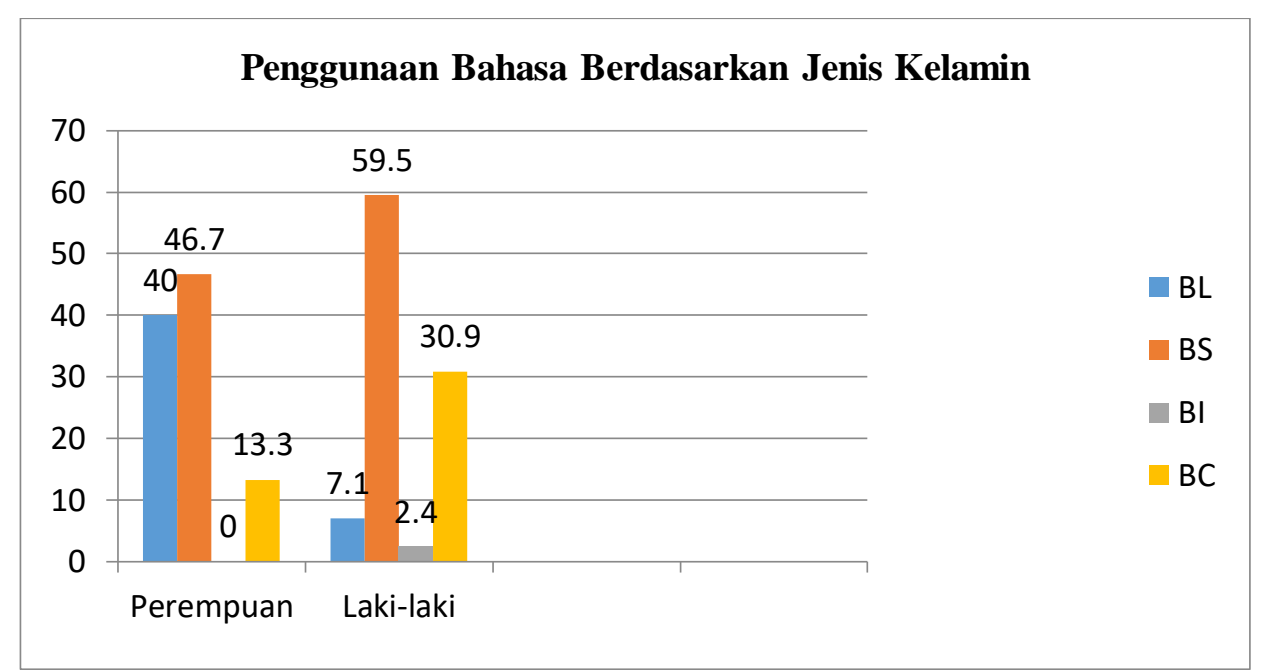

Grafik. 1

Berdasarkan data tersebut dapat dilihat bahwa persentase penggunaan bahasa Selayar pada kedua kategori responden lebih tinggi dibandingkan dengan penggunaan bahasa Lowa dan persentase penggunaan bahasa Selayar tertinggi terdapat pada responden laki-laki. Selain itu, penggunaan atau penguasaan bahasa pada responden laki-laki juga lebih banyak daripada responden perempuan. Hal tersebut disebabkan oleh aktivitas atau pekerjaan mereka cenderung lebih banyak di luar rumah atau di luar wilayah, sehingga bahasa yang mereka gunakan pun harus disesuaikan dengan bahasa orang-orang yang ada di lingkungan kerja mereka. Berbeda dengan perempuan, aktivitas atau pekerjaan mereka lebih banyak di lingkungan rumah tangga atau di dalam wilayah mereka, sehingga bahasa yang digunakan pun tidak terlalu bervariasi seperti pada responden laki-laki

Perbedaan pada jenis kelamin banyak digunakan oleh para peneliti pergeseran maupun pemertahanan bahasa sebagai salah satu variabel. Variabel jenis kelamin ini dianggap penting dan seringkali menjadi salah satu faktor pergeseran bahasa atau pemertahanan bahasa. Hal tersebut disebabkan oleh adanya perbedaan aktivitas antara laki-laki dan perempuan. Umumnya laki-laki lebih banyak beraktivitas di luar rumah bahkan sampai keluar daerah atau wilayah pemukiman, sehingga mereka lebih banyak berbaur dengan masyarakat dari daerah lain yang memiliki bahasa dan budaya yang berbeda, sedangkan perempuan umumnya lebih banyak beraktivitas di dalam rumah atau di lingkungan rumah tangga sehingga tidak terlalu mendapat pengaruh atau pengetahuan mengenai bahasa-bahasa atau budaya baru.

Berdasarkan hasil uji statistik yang dilakukan, diperoleh bahwa nilaii $-\mathrm{p}$ (sig.) $=0,004$ lebih kecil dari taraf keberartian alpha=0,05 (signifikan), dengan demikian disimpulkan bahwa ada pengaruh jenis kelamin (X2) terhadap pergeseran bahasa Lowa. Faktor intensitas komunikasi di ranah rumah tangga masih tergolong tinggi disebabkan responden wanita di lingkungan rumah tangga senantiasa menggunakan bahasa Lowa sebagai bahasa sehari-hari sehingga faktor ini tidak menyebabkan terjadinya pergeseran. Hanya saja faktor masyarakatnya yang multilingual yang menyebabkan terjadinya pergeseran bahasa Lowa khususnya bagi responden laki-laki yang membangun komunikasi dengan wilayah luar dan tidak menggunakan bahasa Lowa. 


\section{Penggunaan Bahasa Berdasarkan Umur}

Perbedaan umur seringkali menghasilkan penggunaan bahasa yang berbeda pula, hal tersebut disebabkan oleh tingkat penguasaan bahasa pada setiap kelompok atau kategori umur yang berbeda. Berdasarkan hasil penelitian ditemukan penggunaan atau pemakaian bahasa yang berbeda pada setiap kelompok atau kategori umur dalam melakukan aktivitas mereka sehari-hari.

Pada responden yang berusia 11-15 tahun, yang memakai bahasa Lowa 0\%, bahasa Selayar $85,7 \%$, bahasa Indonesia $0 \%$, dan bahasa campuran $14,3 \%$. Pada responden yang berusia 16-27 tahun, yang memakai bahasa Lowa 8,3\%, bahasa Selayar 75\%, bahasa Indonesia $16,7 \%$, dan bahasa campuran $0 \%$. Pada responden yang berusia 28-49 tahun, yang memakai bahasa Lowa 28,6\%, bahasa Selayar 42,6\%, bahasa Indonesia 0\%, dan bahasa campuran $28,6 \%$. Pada responden yang berusia di atas 50 tahun, yang memakai bahasa Lowa $55,6 \%$, bahasa Selayar 16,7\%, bahasa Indonesia 0\%, dan bahasa campuran 27,8\%. Lebih jelasnya dapat dilihat pada Grafik 2.

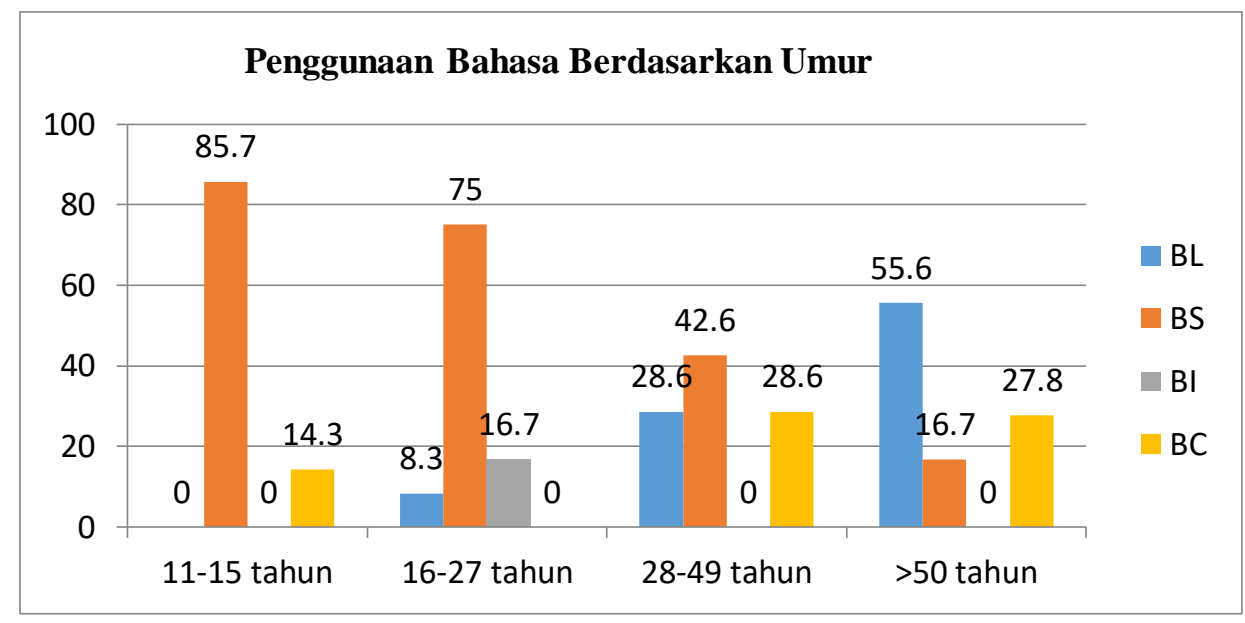

Grafik. 2

Data tersebut menunjukkan bahwa penggunaan bahasa Selayar sangat dominan pada tiga kelompok umur yaitu 11-15 tahun, 16-27 tahun, dan 28-49 tahun. Adapun persentase tertinggi penggunaan bahasa Selayar berada pada kelompok umur 11-15 tahun yakni 85,7 \%, dan pada kategori umur ini juga tidak terdapat responden yang menggunakan bahasa Lowa. Sementara itu, persentase penggunaan bahasa Lowa tertinggi berada pada kelompok umur 50 tahun ke atas yakni 55,6\%. Data di atas juga sekaligus menunjukkan bahwa semakin muda umur responden maka tingkat penguasaan dan penggunaan bahasa Lowa mereka semakin berkurang atau tidak menguasai sama sekali. Hal tersebut juga secara tidak langsung menandakan bahwa semakin muda umur responden, tingkat pergeseran bahasa Lowa yang terjadi semakin tinggi. Persentase tertinggi penggunaan bahasa Lowa pada responden yang berusia di atas 50 tahun disebabkan oleh mereka masih setia pada bahasa pertama mereka. Faktor lain yang menyebabkan hal tersebut adalah responden yang berada pada kelompok umur ini memiliki penguasaan atau pemahaman yang terbatas terhadap bahasa lain selain bahasa pertama mereka.

Umur merupakan salah satu variabel penting dalam penelitian pergeseran maupun pemertahanan suatu bahasa. Hasil uji statistik menunjukkan bahwa nilai - $p($ sig $)=0,000$ lebih kecil dari taraf keberartian alpha $=0,05$, (signifikan). Hal tersebut menandakan bahwa umur memiliki pengaruh terhadap pergeseran bahasa Lowa. 
Berdasarkan informasi yang diperoleh dari Bapak Alwi (41 tahun), yang mengatakan bahwa masyarakat Lowa yang berumur lebih muda dari dirinya umumnya sudah tidak menguasai bahasa Lowa, meskipun ada itu hanya sebatas mereka mengetahui artinya tanpa dapat mengucapakan (pasif-reseptif). Hal tersebut disebabkan mereka tidak memeroleh bahasa Lowa dari orang tua mereka atau dengan kata lain bahasa yang diajarkan oleh orang tua mereka sejak kecil adalah bahasa Selayar, sementara bahasa Lowa mereka peroleh atau mereka dengar dari para orang tua yang berbicara di dalam lingkungan masyarakat seharihari. Selain itu, Sejalan dengan itu bapak Muh. Yamin (50 tahun) juga mengungkapkan bahwa masyarakat di Lowa umumnya sudah menggunakan bahasa Selayar, sehingga pengetahuan anak-anak dan anak muda tentang bahasa Lowa sudah sangat kurang. Dia juga mengungkapkan bahwa yang menguasai bahasa Lowa dengan baik hanyalah orang tua yang berumur sekitar 80 tahun ke atas. Fenomena ini disebabkan oleh intensitas penggunaan bahasa di lingkungan rumah tangga khususnya untuk generasi muda, sehingga dapat disimpulkan bahwa terdapat kesenjangan yang sangat besar antara generasi tua dan generasi muda dalam menggunakan bahasa Lowa

Hasil uji statistik menguatkan hasil wawancara sebelumnya bahwa dari keempat generasi yang ada, generasi keempat (11-15 tahun) tingkat pergeseran bahasa Lowa paling tinggi, lebih tinggi daripada generasi ketiga (16-27 tahun), generasi ketiga ini pun tingkat pergeseran bahasanya lebih tinggi dari generasi kedua (28-49 tahun) dan generasi kedua ini juga tingkat pergeseran bahasanya lebih tinggi dari generasi pertama (50 tahun ke atas). Fenomena ini menunjukkan bahwa semakin lama tingkat penguasaan dan pemakaian bahasa Lowa pada masyarakat Lowa semakin berkurang.

\section{Penggunaan Bahasa Berdasarkan Tingkat Pendidikan}

Perbedaan tingkat pendidikan seringkali menimbulkan pemilihan bahasa yang berbeda dalam komunikasi sehari-hari. Adapun tingkat pendidikan yang diambil sebagai variabel dalam penelitian ini adalah mulai dari SD/TTSD-PT. Berdasarkan hasil penelitian diperoleh penggunaan bahasa pada responden sebagai berikut. Pada responden yang memilki tingkat pendidikan TTSD/SD, yang memakai bahasa Lowa 42,9\%, bahasa Selayar 35,7\%, bahasa Indonesia $7,1 \%$, dan bahasa campuran $14,3 \%$. Pada responden yang memiliki tingkat pendidikan SMP, yang memakai bahasa Lowa $4 \%$, bahasa Selayar $68 \%$, bahasa Indonesia $8 \%$, dan bahasa campuran $20 \%$. Pada responden yang memilki tingkat pendidikan SMA, yang memakai bahasa Lowa 16,7\%, bahasa Selayar 55,6\%, bahasa Indonesia 5,6\%, dan bahasa campuran $22,2 \%$. Pada responden yang memilki tingkat pendidikan S1/PT, yang memakai bahasa Lowa 6,7\%, bahasa Selayar 40\%, bahasa Indonesia 20\%, dan bahasa campuran 33,3\%. Hal ini ditunjukkan pada Grafik 3 tentang penggunaan bahasa berdasarkan tingkat pendidikan responden. 


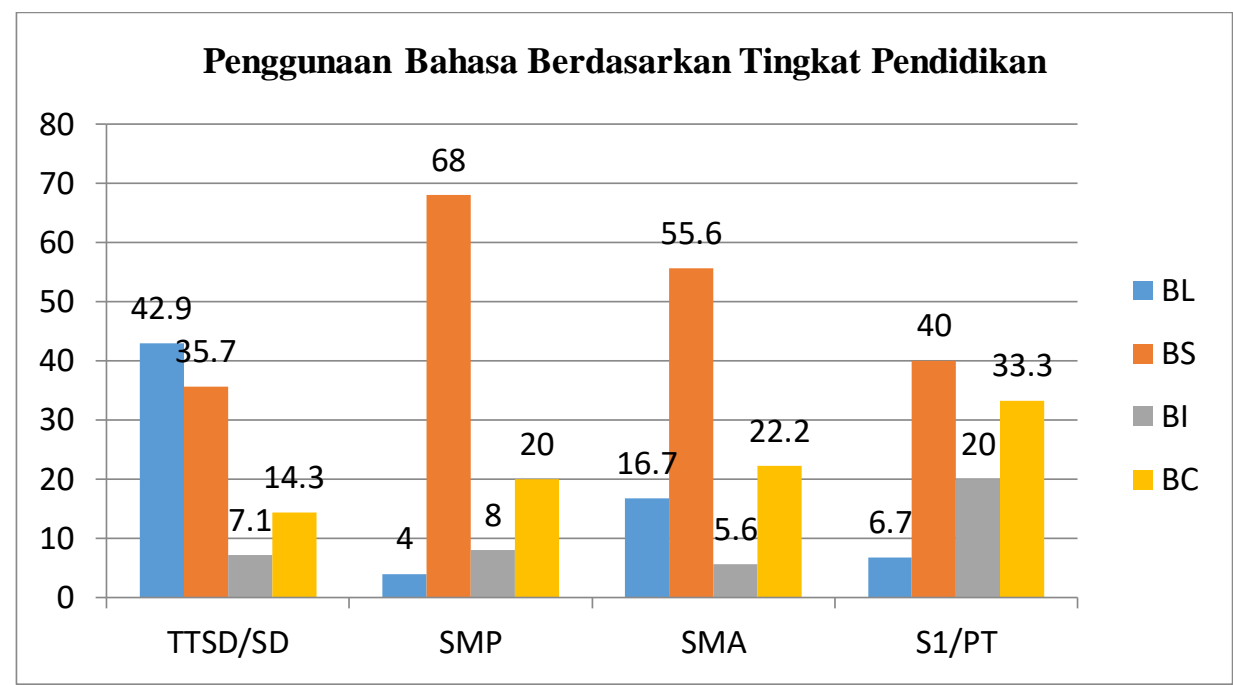

Grafik 3

Berdasarkan data tersebut, persentase tertinggi penggunaan bahasa Lowa berada pada responden yang memilki tingkat pendidikan TTSD/SD, sedangkan pada responden lain yang memiliki tingkat pendidikan yang lebih tinggi persentase penggunaan bahasa yang paling tinggi adalah bahasa Selayar. Hal tersebut cukup beralasan karena pada tingkat pendidikan seperti ini responden sudah berbaur dengan banyak orang yang berasal dari luar daerah mereka, sehingga bahasa yang digunakan pun bervariasi. Hal ini juga tentu saja secara tidak langsung memberikan pemahamana atau pengetahuan baru terhadap perbendaharaan bahasa pada diri responden tersebut, sehingga tidak mengherankan jika kemudian responden yang memiliki tingkat pendidikan yang lebih tinggi menggunakan banyak bahasa atau variasi bahasa dalam kehidupan sehari-hari mereka.

Tingkat pendidikan juga menjadi salah satu faktor penting dalam pergeseran bahasa. Beberapa penelitian mengenai pergeseran dan pemertahanan bahasa menemukan bahwa semakin tinggi tingkat pendidikan maka semakin tinggi pula peluang terjadinya pergeseran bahasa Lowa pada responden. Pendidikan menjadi salah satu alasan seseorang meninggalkan bahasa daerahnya. Semakin tinggi pendidikan seseorang maka semakin besar mereka meninggalkan bahasa derahanya (Nenoliu \& Mardikantoro, 2019).

Dalam penelitian ini tingkat pendidikan yang menjadi indikator adalah mulai dari SDPT. Berdasarkan data yang diperoleh, secara umum responden yang berpendidikan pada tingkat SD atau tidak tamat SD mengaku masih menguasai bahasa pertama dengan baik dengan kata lain pada tingkat aktif produktif, sedangkan pada responden yang memiliki tingkat pendidikan yang lebih tinggi umumnya mengaku hanya dapat mengartikan dan kurang bisa mengucapkan bahasa Lowa.

Berdasarkan hasil uji statistik yang dilakukan, diperoleh nilai-p(sig.)=0,02 lebih kecil dari taraf keberartian alpha $=0,05$ (signifikan). Berdasarkan data tersebut disimpulkan bahwa ada pengaruh tingkat pendidikan terhadap pergeseran bahasa Lowa.

\section{Penggunaan Bahasa Berdasarkan Pekerjaan}

Pekerjaan juga menjadi salah satu faktor pergeseran bahasa. Hal tersebut disebabkan oleh pekerjaan responden yang bervariasi sehingga memungkinkan responden bertemu dan bergaul dengan orang-orang yang berasal dari wilayah atau daerah yang berbeda. Berdasarkan data penelitian pergeseran bahasa Lowa terjadi pada setiap jenis pekerjaan atau profesi atau dengan kata lain bahasa Selayar mendominasi pada semua jenis pekerjaan. Hal tersebut sangat beralasan mengingat bahasa Selayar tersebut merupakan bahasa yang umum digunakan di 
Selayar, sehingga mau tidak mau dalam melakukan aktivitas atau pekerjaan, mereka harus menggunakan bahasa yang banyak digunakan di tempat mereka bekerja. Dengan menggunakan bahasa yang dominan digunakan oleh masyarakat, mereka bisa lebih mudah melakukan interaksi dengan orang lain yang ada di sekeliling mereka atau di sekitar tempat mereka bekerja.

Salah satu kemudahan atau keuntungan yang diperoleh dengan menggunakan bahasa Selayar dalam melakukan pekerjaan diungkapkan oleh seorang responden, ibu Mandiri (71 tahun) yang berprofesi sebagai pedagang, dia menuturkan bahwa dengan menggunakan bahasa Selayar dia lebih mudah melayani konsumen serta menawarkan barang dagangannya kepada pembeli yang datang berbelanja ke tokonya. Hal tersebut secara tidak langsung menandakan bahwa penggunaan bahasa Selayar dalam melakukan pekerjaan tidak hanya memudahkan dalam melakukan pekerjaan, tetapi juga memeberikan keuntungan secara ekonomi. Atas dasar itu pula lah masyarakat Lowa (responden) lebih memilih menggunakan bahasa Selayar dibandingkan bahasa Lowa dalam melakukan pekerjaan mereka.

Berdasarkan hasil uji statistik yang dilakukan, ditemukan nilai-p(sig. $)=0,001$ lebih kecil dari taraf keberartian alpha $=0,05$ (signifikan). Berdasarkan data tersebut disimpulkan bahwa ada pengaruh pekerjaan terhadap pergeseran bahasa Lowa.

Empat faktor sosial yang telah dikemukakan di atas menggambarkan bahwa bahasa Lowa di etnis Lowa pada umumnya mulai tergeser dan digantikan oleh bahasa daerah Selayar atau bahasa Indonesia. Jika dilihat pada setiap poin faktor sosial tersebut, peneliti menemukan suatu hal yang berbeda dari beberapa penelitian pergeseran bahasa yang telah diungkapkan sebelumnya baik oleh Lukman (2014) bahwa faktor lingkungan kerja juga sangat berperan menyebabkan terjadinya pergeseran bahasa, G. Lukman (2015) yang mengungkapkan bahwa pengaruh sikap dapat menyebabkan pergeseran bahasa oleh masyarakat, selian itu, faktor pendidikan juga sangat mempengaruhi pergeseran bahasa (Nenoliu \& Mardikantoro, 2019). Penelitian ini menunjukkan bahwa faktor paling dominan yang sangat mempengaruhi pergeseran bahasa Lowa di Etnis Lowa di Sulawesi Selatan adalah faktor umur. Faktor umur ini disebabkan oleh adanya gap antara generasi tua dan generasi muda. Generasi muda pada umumnya berada pada kategori pasif-reseptif dalam penggunaan bahasa Lowa. Pemahaman pasif-reseptif yang mereka peroleh hanya melalui kegiatan komunikasi antar sesama generasi tua. Akibatnya, mereka hanya mampu memahami beberapa bahasa Lowa secara pasif, tidak mampu menggunakan bahasa Lowa secara lisan dan tulisan, bahkan ada pula diantara mereka yang sama sekali tidak memahami bahasa Lowa meskipun mereka adalah etnis Lowa itu senidiri.

Temuan penelitian ini juga memberikan gambaran bahwa konteks faktor sosial yang mempengaruhi pergeseran bahasa Lowa sudah memasuki arah kepunahan bahasa Lowa itu sendiri. Hal ini disebabkan oleh beberapa komponen dalam temuan ini sejalan dengan sepuluh faktor penyebab kepunahan bahasa yang diungkapkan oleh Tondo (2009) dan lima dari sepuluh faktor tersebut meliputi: (1) pengaruh bahasa mayoritas, (2) dan lima dari sepuluh faktor tersebut yaitu meliputi: (1) pengaruh bahasa mayoritas yang ada di Etnis Lowa saat ini bukan lagi bahasa Lowa, melainkan bahasa Selayar, (2) kondisi di etnis Lowa saat ini pada umumnya penutur yang multilingual, (3) tuntutan era globalisasi sehingga, sebagian besar dari etnis Lowa mengikuti perkembangan zaman tetapi tidak mempertahankan bahasa Lowa dalam berkomunikasi antar sesama etnis Lowa, (4) intensitas penggunaan bahasa Lowa yang hanya dilakoni sebagian besar oleh generasi tua (5) tuntutan ekonomi yang menyebabkan para etnis Lowa harus memilih menggunakan bahasa Selayar atau bahasa Indoesia sebagai salah satu bahasa yang sering digunakan di perniagaan. 


\section{SIMPULAN}

Berdasarkan hasil penelitian, disimpulkan bahwa faktor sosial yang memengaruhi pergeseran bahasa Lowa antara lain faktor umur; faktor, jenis kelamin; dan faktor tingkat pendidikan. Adapun faktor sosial yang dominan memengaruhi pergeseran bahasa Lowa yaitu faktor tingkat pendidikan. Selain itu, berdasarkan penggunaan bahasa juga disimpulkan bahwa status bahasa Lowa telah berada di ambang kepunahan (nearly extinct) yang penuturnya hanya menyisakan sebagian atau beberapa orang tua saja.

\section{UCAPAN TERIMA KASIH}

Penelitian ini merupakan penelitian yang disponsori oleh Kementerian Riset dan Pengabdian Masyarakat Direktorat Jenderal Penguatan Riset, Teknologi, dan Pendidikan Tinggi melalui program hibah penelitian dosen pemula (PDP) pendanaan tahun 2019.

\section{DAFTAR PUSTAKA}

Anderson, T. D. (2010). Pelestarian dan Pengembangan Bahasa Moronene. Paper presented at the Makalah disamapaikan Kongres Internasional Bahasa-bahasa Daerah Sulawesi Tenggara, Bau-Bau, Sulawesi Tenggara.

Darwis, M. (2011). Nasib Bahasa Daerah di Era Globalisasi: Peluang dan Tantangan. Paper presented at the Makalah disampaikan pada Workshop Pelestarian Bahasa Daerah Bugis Makassar, Parepare.

Diani, I. (2011). Pergeseran dan Pemertahanan Bahasa Serawai di Tengah Hegemoni Bahasa Melayu Bengkulu di Kota Bengkulu Serawai. In N. Mckinnon, A. Subiyanto, M. Suryadi, \& S. Waluyo (Ed.), Language Maintenance and Shift Semarang: Pustaka Cahaya.

Donohue, M. (2004). The Pretenders to the Muna-Buton Group. Paper presented at the Papers in Austronesian Subgrouping and Dialectology.

Eliya, I., \& Zulaeha, I. (2017). Pola Komunikasi Politik Ganjar Pranowo dalam Perspektif Sosiolinguistik di Media Sosial Instagram. Seloka: Jurnal Pendidikan Bahasa Dan Sastra Indonesia, 6(3), 286-296.

Ibrahim, G. A. (2011). Bahasa Terancam Punah: Fakta, Sebab-Musabab, Gejala, dan Strategi Perawatannya. Linguistik Indonesia, 29(1), 35-52.

Lukman. (2014). Pergeseran Bahasa-Bahasa Daerah di Sulawesi Selatan: Kasus Pergeseran Bahasa Bugis, Makassar, Toraja, dan Enrekang.

Lukman, G. (2015). Local Languages Shift in South Sulawesi; Case Four Local Languange (Bugis, Makassar, Toraja, Enrekang). Journal of Language and Literature, 6(3), 151154.

Mardikantoro, H. (2012). Bentuk Pergeseran Bahasa Jawa Masyarakat Samin dalam Ranah Keluarga. LITERA, 11(2), 204-215.

Mardikantoro, H. B., \& Maretta, Y. A. (2016). Language Shift of Javanese And Its Impacts on The Transformation of Samin Community. Man In India, 96(11), 4167-4180.

Mukhamdanah. (2010). Satu Bahasa Ibu di Indonesia Telah Punah (lagi): Kasus Bahasa Tandia di Teluk Wondama. Paper presented at the Seminar Internasional Menyelamatkan Bahasa Ibu Sebagai Kekayaan Budaya Nasional, Bandung.

Nenoliu, D. S., \& Mardikantoro, H. B. (2019). Dawan Language Shift in Amanuban Society in Family Context. Seloka: Jurnal Pendidikan Bahasa Dan Sastra Indonesia, 8(2), 713.

Raihany, A. (2015). Pergeseran Penggunaan Bahasa Madura di Kalangan Anak-anak Sekolah Dasar Negeri di Desa Pangarangan Kecamatan Kota Sumenep. NUANSA: Jurnal Penelitian Ilmu Sosial dan Keagamaan Islam, 12(1), 53-84. 
Suparta, H. (2015). Pengikisan Bahasa dalam Masyarakat Jawa Catatan tentang Proses Kepunahan Bahasa Jawa. Sabda: Jurnal Kajian Kebudayaan, 10(2), 1-16.

Tamrin, N. (2018). Pemilihan Bahasa dalam Ranah Keluarga: Studi Kasus Pemilihan Bahasa Bugis oleh Etnis Bugis di Kabupaten Donggala Sulawesi Tengah Multilingual, 12(2), 145-157.

Tondo, H. (2009). Kepunahan Bahasa-Bahasa Daerah: Faktor Penyebab dan Implikasi Etnolinguistis. Jurnal Masyarakat dan Budaya, 11(2), 277-296.

Wael, A., Asnur, M. N. A., \& Ibrahim, I. (2018). Exploring Students Learning Strategies in Speaking Performance International Journal of Language Education, 2(1), 65-71.

Widianto, E., \& Zulaeha, I. (2016). Pilihan Bahasa dalam Interaksi Pembelajaran Bahasa Indonesia bagi Penutur Asing. Seloka: Jurnal Pendidikan Bahasa Dan Sastra Indonesia, 5(2), 124-135.

Wodak, R., Krzyżanowski, M., \& Forchtner, B. (2012). The Interplay of Language Ideologies and Contextual Cues in Multilingual Interactions: Language Choice and CodeSwitching in European Union Institutions. Language in Society, 41(2), 157-186. 